\title{
Research on Classroom Teaching Model Based on Flipped Classroom
}

\author{
Chen LU* \\ Suzhou Industrial Park Institute of Services Outsourcing \\ Suzhou, China \\ luc@siso.edu.cn
}

\author{
Xianjing SHI \\ Suzhou Industrial Park Institute of Services Outsourcing \\ Suzhou, China
}

\begin{abstract}
Because of the existence of such phenomena as ineffective learning methods, poor study habits and lack of learning interest for vocational college students, a teaching model based on flipped classroom is proposed in this paper. This model adopts multiple teaching modes before class, in class and after class to improve the efficiency of learning, and develop students learning initiative, self-study ability, independent thinking skills as well as teamwork spirits. Through a year's practice, positive effect has been achieved.
\end{abstract}

Keywords-flipped classroom; teaching mode; vocational college students

\section{INTRODUCTION}

Flipped Classroom refers to an instructional strategy that readjusts the time both inside and outside classroom and shifts decision-making power of learning from the teacher to the students. In this model of classroom instruction, students are able to focus more on proactive, project-based learning tasks, and teachers no longer focus on an explanation of content utilizing a lecture-style. Students gain first exposure to new material outside of class, usually via reading or lecture videos, listen to podcasts and read eBooks. They can chat with other students online and check out the materials they need at any time. Teachers also have more time to communicate with everyone. After class, students autonomously plan their learning content, learning style and presentation of knowledge. They may choose to learn at their own pace. Teachers use lectures and collaboration methods to meet the needs of students and facilitate their personalized learning. It is aimed at helping students to have exposure to more knowledge via practice.

Flipped Classroom was originated in Woodland Park High School in Colorado, USA in 2007. Two chemistry teachers at the school recorded their lectures and posted them online to enable students to watch videos at home. It moves activities, including those that may have traditionally been considered homework, into the classroom. Problems encountered in study can be sorted out in the classroom. This teaching mode is warmly welcomed by students. Afterwards, with the popularization of Global campaign for Open Teaching Resources, massive high-quality teaching resources such as

2017 Jiangsu Provincial Higher Education Teaching Reform Research Project named "Research and Practice of the Wisdom Classroom Teaching Model under the Background of Internet and Education”, -2017jsjg081.

2017 Jiangsu Provincial 3rd Vocational Education Teaching Reform Research Project named "Research on the Teaching Mode of Mobile Internet Based on Outstanding Works”, -ZYB276
Yale Open Class, Khan Academy Micro Video and TED ED (TED Education Channel) video were provided. They provided abundant high-quality resources for flipped classroom, greatly promoting flipped classroom model. [1]

In the late 1990s, some high schools in China were exploring teaching methods like flip classrooms. Especially after 2010, large-scale open online courses were launched around the world. A large number of outstanding teaching resources and videos were spread on the Internet to promote the development of Flipped Classroom. Researchers from Tsinghua University put forward a "Tai Chi Central" flip classroom model. [2] Professor Jiang Yulong from Fudan University presided over and implemented a project in which flipped model was used in "Semiconductor Physics" course. He proved the excellent teaching effect of flipped model with lots of data. Students not only learned the knowledge but also had the initiative to learn. Nowadays, there has been found varying differences in the method of implementation of this model in more and more university classrooms, especially the 985 and 211 universities. In vocational colleges, similar models are also employed in the teaching process.

\section{An Analysis of Vocational College StUdents' LEARNING FEATURES}

Quite different from flipped classroom mode implemented in universities, the learning features of students in vocational colleges are as follows:

Learning Interest: Students in vocational colleges are more emotional and have enthusiasm for topics that interest them. Boring topics, on the other hand, may prove to decrease their learning efficiency.

Learning Motivation: The motivation for vocational college students to learn is varied, but it may also change with the different social and historical conditions of students and their different personal experiences. Their learning motivation is not stable at all.

Learning styles: Students of vocational colleges have a higher level of professional orientation. When they first enter the school, they have already understood their future jobs, and focused on certain occupational orientation to learn basic courses and specialized courses.

Learning methods: Study in vocational college is different from that in secondary school. Students need time to adapt themselves to the new learning environment after they set foot 
on the new campus. How to help the freshmen adapt to the study life of vocational colleges as soon as possible not only involves the teaching methods but also students' learning strategies. Vocational school students' learning initiative is still relatively poor. Most of them don't have the habit to take notes in class. [3]

Based on the above learning features, we cannot use the general flipped classroom teaching mode. Instead, we need to adopt teaching strategies that can enhance students' interest and improve their self-confidence to assist the implementation of flipped model.

\section{An Analysis of Vocational College Students' GENERIC SKILLS}

According to a survey carried out by Suzhou Industrial Park Institute of Services Outsourcing, a total of 130 questionnaires were handed out to 61 enterprises and 116 copies were collected. These enterprises selected 15 core skills of vocational college graduates and chose the five abilities that were considered to be the most important(Fig. I). Through frequency analysis, the core skills most valued by the employers are: learning ability, communication skills, teamwork spirits, executive ability, interpersonal skills, psychological endurance and ability for making analysis and judgment.

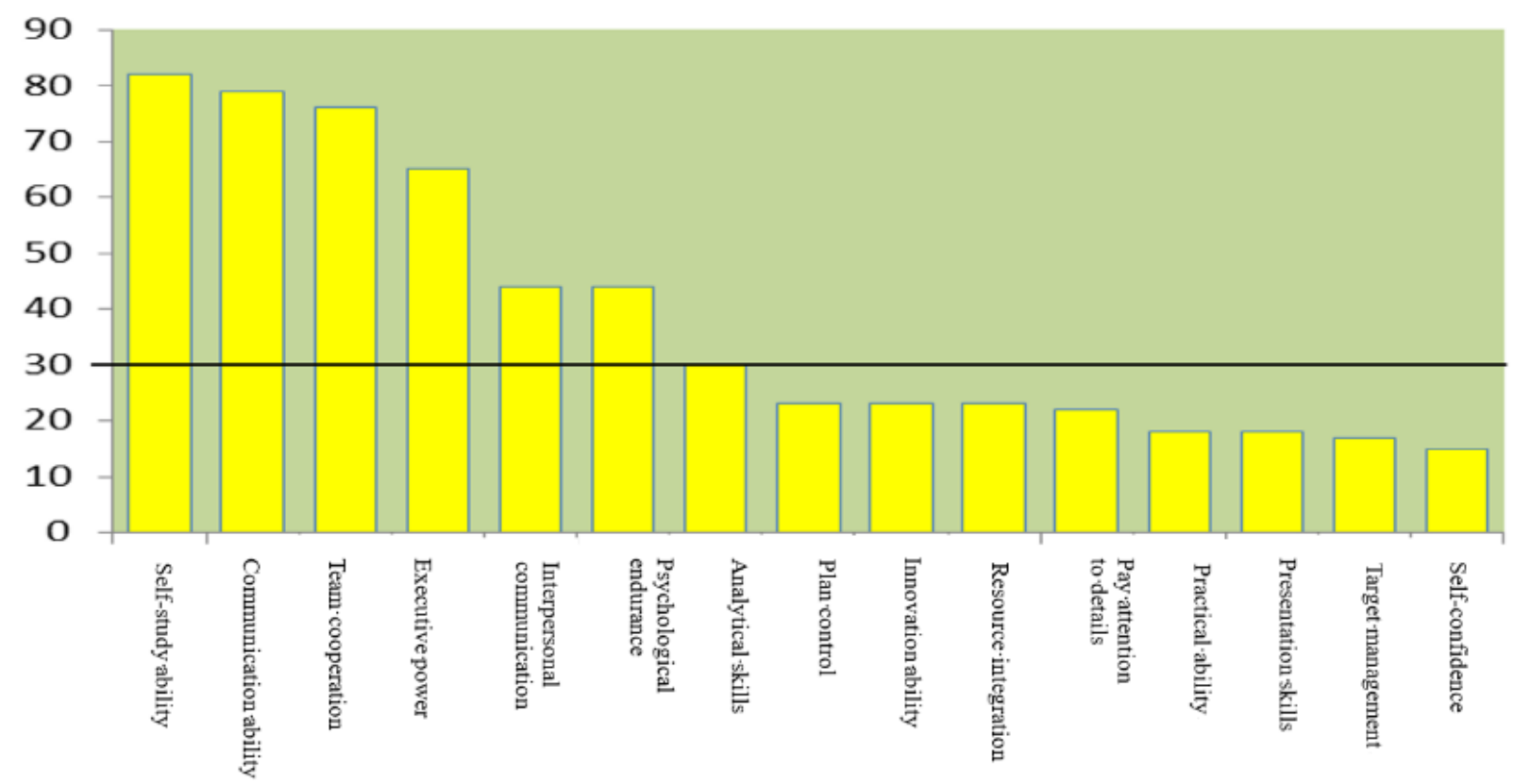

Fig. 1. Vocational College Students’ Generic Skills

\section{Flipped Classroom Teaching Mode Suitable for VOCATIONAL STUDENTS}

This paper proposes a teaching model based on flipped classroom (Fig. II). This model effectively presents students' learning content before class, during class and after class. The following teaching modes are used: inquiry teaching, heuristic teaching, case study and other common teaching modes. Class activities vary but may include: video, Questions and Answers, quizzes, exercises and case analysis. The flipped classroom intentionally shifts instruction to a learner-centered model in which students are more enthusiastic about study. Teachers, originally the central focus of a lesson, have become curriculum designer and organizers. Take a class of 2 hours for example. The activities before, during and after class are shown in Table I.

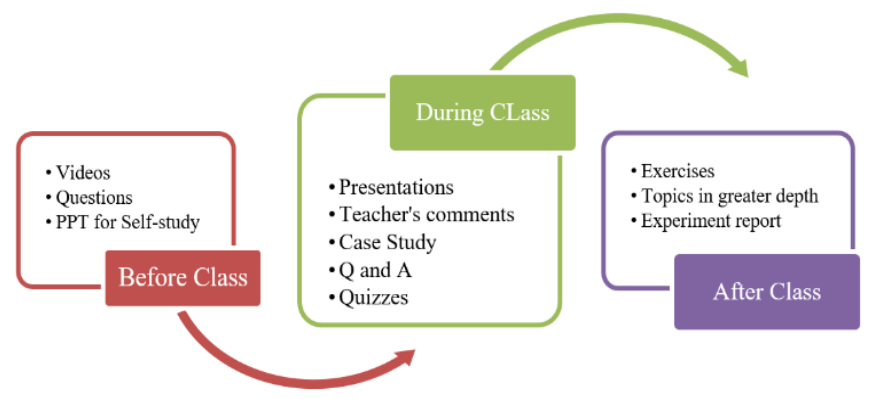

Fig. 2. Classroom Teaching Model Based on Flipped Classroom

Faced with the situation of vocational college students, it is essential to strengthen the weakest skills of students by implementing the above flipped classroom teaching mode. Students' main abilities are shown in Table II. 
TABLE I. STEPS FOR IMPLEMENTING FLIPPED CLASSROOM TEACHING MODE

\begin{tabular}{|c|c|c|c|c|}
\hline Phases & Teaching content & Time & Teaching modes & Teaching methods \\
\hline \multirow{3}{*}{ Before class } & videos & 15 minutes & heuristic teaching mode & $\begin{array}{l}\text { Teachers provide videos } \\
\text { Self-study for students }\end{array}$ \\
\hline & Answer questions & 15 minutes & heuristic teaching mode & $\begin{array}{l}\text { Teachers provide questions } \\
\text { Self-study for students }\end{array}$ \\
\hline & Prepare PPT for self-study & 30 minutes & inquiry teaching mode & Group discussion Self-study for students \\
\hline \multirow{5}{*}{ During Class } & $\begin{array}{c}\text { Presentations } \\
\text { Peer questions and ans wers }\end{array}$ & 15 minutes & students’ presentation & $\begin{array}{l}\text { Randomly select } 2 \text { to } 3 \text { groups of students to report self-study content. } \\
5 \text { minutes for each group }\end{array}$ \\
\hline & $\begin{array}{c}\text { Teacher's comment } \\
\text { Knowledge supplement }\end{array}$ & 10 minutes & Teacher's analysis & Discussion \\
\hline & Case Study & 15 minutes & Case study & Teacher offers explanation \\
\hline & Practice & 25 minutes & Practice & $\begin{array}{l}\text { Teacher offers guidance } \\
\text { Students make practice }\end{array}$ \\
\hline & Quizzes & 10 minutes & & Quizzes \\
\hline \multirow[b]{2}{*}{ After class } & Exercises & 10 minutes & heuristic teaching mode & Complete exercise independently \\
\hline & $\begin{array}{l}\text { Advanced case study } \\
\text { Experiment report }\end{array}$ & 30 minutes & inquiry teaching mode & Group discussion \\
\hline
\end{tabular}

Through a year's practice, students have a great interest in presentation. This has changed traditional model of classroom instruction in which the teacher is typically the primary disseminator of information during the class period. Students are required to acquire new knowledge in just one or two lessons. Students and teachers are less likely to have interactions in class. They are more proactive than their counterparts. With presentations, questions, assessment and other strategies, students are able to have more definite goals.

TABLE II. STUDENT S’ CORRESPONDING ABILIT IES NEEDED FOR DIFFERENT TEACHING TASKS

\begin{tabular}{|c|c|}
\hline Teaching tasks & Students' ability \\
\hline Pre-class video watching & self - study ability, comprehensive ability \\
\hline Pre-class questions & $\begin{array}{c}\text { independent thinking skills } \\
\text { comprehensive ability }\end{array}$ \\
\hline Pre-class PPT for self-study & summing-up skills \\
\hline In-class presentations & presentation skills, self-confidence \\
\hline Peer questions and answers & Thinking skills, analytical skills \\
\hline Teacher's comments & Thinking skills, analytical skills \\
\hline While-tasks & Practical ability, ability of raising question \\
\hline Quizzes & Learning ability, timely mastery \\
\hline $\begin{array}{c}\text { After-class Advanced case } \\
\text { study }\end{array}$ & Higher-order thinking skills \\
\hline
\end{tabular}

\section{CONCLUSION}

Flipped Classrooms proposed in this paper have been implemented in class. Various teaching methods are employed in the pre-class, in-class and after-class teaching tasks.
Teaching resources vary but may include: videos, questions, exercises, cases and etc. This may ensure the success of three-dimensional offline teaching process, developing students' self-learning skills, independent thinking skills, presentation skills and teamwork spirits. In a flipped classroom, students are more than happy to learn and their interest and learning effectiveness have been significantly improved. A teacher's interaction with students in a flipped classroom can be more personalized and less didactic. Students' learning skills and comprehensive abilities have become better.

In the process of implementation, we also encountered many problems, such as the limitation of students' abilities, their lack of self-learning ability and study habits. Some of the students fish in troubled waters and even give up from time to time. The implementation of flipped classroom requires certain amount of free time after class, which is a challenge for vocational students who have poor time-management. In the face of these problems, we also need more rational and feasible teaching methods to start implementing flipped model when they are freshmen for the development of their personal abilities.

\section{REFERENCES}

[1] J. ZHNAG, Y. WANG, B. ZHANG, Research on Flipped Classroom Teaching Modes [J]. Distance Education,2012, (4). (In Chinese)

[2] X. ZHONG, S. SONG, L. JIAO. Study on Teaching Design Based on the Concept of Flipped Class in Information Environment [J]. Open Education Research, 2013, 19(1). (In Chinese)

[3] G. ZHANG. New Thoughts on the Reform of "University Computer Basis" Curriculum Based on Flipped Classroom [J]. University Education, 2013(7). (In Chinese) 